\title{
Factor analysis of economic efficiency of the oil and gas industry in Russia
}

\author{
Irina Filimonova ${ }^{1,2, *}$, Anna Komarova ${ }^{1,2}$, and Anastasia Chebotareva ${ }^{1,2}$ \\ ${ }^{1}$ Trofimuk Institute of Petroleum Geology and Geophysics SB RAS, 3, Koptug, 630090, Novosibirsk, \\ Russia \\ ${ }^{2}$ Novosibirsk State University, 1, Pirogova, 630090, Novosibirsk, Russia
}

\begin{abstract}
The article presents an analysis of performance indicators of companies in the oil and gas industry of Russia in 2013-2018. The aim of the study is to decompose the factors of change in the return on equity (ROE) of Russian oil and gas companies. The authors used the Dupont method to identify the main factors affecting ROE. After decomposing the ROE into factors, the authors evaluated their impact using the Logarithmic Mean Divisia Index (LMDI-1). As a result of the study, it was found that in most companies the greatest impact on the change in ROE has a return on sales, primarily as a result of revenue growth due to favorable oil prices and positive exchange rate differences. Simultaneously, sales profitability has a positive effect on the index of almost all companies in the industry. Asset turnover also had only a positive effect on ROE. However, a comparison of the results for 2017 and 2018 showed a significant difference in performance for many companies. Thus, we can conclude that the effect of a certain factor on the profitability of sales largely depends on the development strategy of the company for the coming year, the economic and political situation.
\end{abstract}

\section{Introduction}

Over the past decade and a half, there has been a significant increase in the resource and raw materials orientation of the development of the Russian economy, based on income from the extraction and export of hydrocarbons. Until 2014, revenues from the oil and gas sector in the structure of federal budget revenues increased to $50 \%$, and taking into account other general business taxes in the industry, this indicator increased to almost $65 \%$. In the structure of the balance of payments reflecting foreign economic operations, foreign exchange earnings from hydrocarbon exports increased to $70 \%$ [1].

Sustainable development of the oil and gas industry in Russia is associated with the influence of a number of factors, such as raw materials, organizational, institutional, foreign economic, macro and microeconomic factors [2].

In the face of challenges from domestic and foreign markets, oil and gas companies continue to increase sales revenue and generate profits. This contributes to the sustainable

\footnotetext{
* Corresponding author: Filimonovaiv@list.ru
} 
economic growth of the country as a whole, the implementation of social guarantees of the state and foreign economic obligations [3].

Thus, the purpose of this study is a comprehensive assessment and factor analysis of the dynamics of the financial and economic state of the oil and gas industry in Russia.

Organizational structure of the oil and gas industry in Russia. In 2018, oil and gas condensate production in Russia increased by 9 million tons and amounted to 555.9 million tons. The increase in production is associated with the OPEC + decision to increase production limits since June 2018. As a result, in October 2018, Russia reached a record level of average daily oil production in recent history (1562.7 thousand tons).

Oil and gas condensate production in Russia is carried out by 290 organizations, of which 100 organizations are part of 11 vertically integrated companies (VIOC), mainly oil producers, and two mainly gas and condensate producers. The number of independent mining companies that are not part of the vertically integrated oil companies is 187 . Three companies operate in Russia under production sharing agreements (PSA). [4].

In the structure of oil and condensate production, vertically integrated oil companies account for $80.3 \%$, independent companies produce $16.4 \%$ of hydrocarbons, and PSA accounts for $3.4 \%$ of production.

Among vertically integrated oil companies, Rosneft holds the largest market share. Taking into account the assets of Bashneft, the share of Rosneft in the total volume of oil production in Russia is about $40 \%$. LUKOIL and Surgutneftegas accounted for $14.9 \%$ and $11 \%$ of production, respectively. In total, the three largest oil companies produce more than $64 \%$ of oil in Russia.

The largest increase in oil production in 2018 was recorded by Rosneft ( 5.5 million tons). The increase in oil production by 0.1-0.6 million tons was shown by Tatneft, Lukoil, Surgutneftegas, Russneft. For the second year in a row, Bashneft's production has been declining. At the same time, in 2017, the decrease in production was explained by obligations to limit production under OPEC + . However, according to the results of 2018, despite the removal of obligations, the volume of oil production at the field named after Trebs and Titov continued to decline. Bashneft's total decline in oil production for the year totaled 1.7 million tons.

\section{Data}

The calculations used data that are in the public domain. Data sources are: Consolidated financial statements prepared in accordance with international financial reporting standards (IFRS), Consolidated financial statements prepared in accordance with US GAAP, as well as management reviews of the financial condition and performance of the company (in some companies management reports were used) for period 2011-2017.

1. Data on key indicators (revenue, profit, operating costs, etc.) are presented for the industry as a whole based on the statements of companies. For other companies (a small independent business for which there is no open data), an assessment was made of the Centre of the Economy of subsoil use IPGG SB RAS.

2. In a detailed component-wise breakdown of indicators by structure, the authors used open data for 9 largest oil and gas companies, the total share of hydrocarbon production of which is more than $85 \%$ of the total production level of all Russian companies. Some companies present their own indicator structure, which differs from that adopted by most large companies. In this case, the component-wise structure of the indicators is unified based on the assessment of the Centre of the Economy of subsoil use IPGG SB RAS.

The research methodology is based on an algorithm consisting of an analysis of the organizational and component structure of indicators that determine the revenue of oil and gas companies. Revenue represents cash received from the sale of products and the 
provision of services. This indicator is presented before deducting export duties and excise taxes for each of the 9 major companies and expert evaluation for other companies.

Net profit means the amount of revenue minus all operating expenses (including all tax payments), financial and other expenses and with the addition of operating, financial and other income.

\section{Methodology}

As part of a comprehensive assessment of the financial and economic state of the oil and gas industry in Russia, the authors used the features of the application and the results of calculating the ROE performance indicator, which was modified to be able to compare the performance of companies. Factor analysis was chosen as an additional methodological analysis tool, which allows us to evaluate the contribution of individual components of companies to economic efficiency. For this, we used the decomposition of the ROE indicator into five key factors, the so-called Dupont model decomposition and the LMDI-1 method (Logarithmic Mean Divisia Index) for factor analysis [5, 6].

$\mathrm{ROE}$ is the return on equity or return on capital. This indicator shows how much profit the company generates due to investments by shareholders. [7].

$$
R O E=\frac{N I}{S E}
$$

where ROE is return on equity, $\mathrm{NI}$ is net profit, SE is equity.

With ROE, you can compare how efficiently companies use equity that work in the same industry. Return on equity is important for both investors and owners. First, it allows you to evaluate the profitability of their investments in a particular enterprise, and second, they allow you to evaluate the effectiveness of their activities [8].

The disadvantage of ROE is the impossibility of predicting the profitability of the company, since the indicator does not take into account factors affecting income. Return on equity is not suitable for evaluating the performance of a company that does not have equity $[9,10]$.

The authors used the formula of a five-factor Dupont model for decomposing ROE into net profit elements:

$$
R O E=\frac{N I}{E B T} \times \frac{E B T}{E B I T} \times \frac{E B I T}{R} \times \frac{R}{A} \times \frac{A}{S E}
$$

where NI is net profit, EBT is pre-tax profit, NP/EBT is the tax burden ratio, EBT/EBIT is the percentage burden ratio, $\mathrm{R}$ is revenue, EBIT/R is sales profitability (ROS), A is assets, $\mathrm{R} / \mathrm{A}$ is asset turnover, $\mathrm{SE}$ - equity, $\mathrm{A} / \mathrm{SE}$ - financial leverage.

With its help, from the initial formula for return on equity (1), it was possible to identify the main economic elements that affect ROE: tax and percentage burden ratios, return on sales (ROS), asset turnover and financial leverage.

After decomposing the return on equity into its constituent elements, it is necessary to understand what effect each indicator individually has, whether positive or negative, and to what extent. For this, the authors used the LMDI-1 model (Logarithmic Mean Divisia Index) [11].

To apply this method in the work, the authors modified the formulas taking into account the features of the oil and gas industry and using the profitability of own funds as the analyzed indicator. The calculations did not use summation, since the return on equity was calculated for each analyzed company in the oil and gas sector and for the industry as a whole $(3,4)$. Factor analysis was carried out from 2014 to 2018 due to insufficient data in 
2013 from Lukoil (the company began to publish financial statements used as a data source under IFRS since 2014).

$$
\begin{gathered}
\Delta D_{x^{n}=L\left(R O E_{t}, R O E_{0}\right) * \ln \left(\frac{X_{t}}{X_{0}}\right),} \\
L\left(R O E_{t}, R O E_{0}\right)=\left\{\begin{array}{c}
\frac{R O E_{t}-R O E_{0}}{\ln \left(R O E_{t}\right)-\ln \left(R O E_{0}\right)} ; \text { for } R O E_{t} \neq R O E_{0} \\
R O E_{t} ; \text { for } R O E_{t}=R O E_{0}
\end{array},\right.
\end{gathered}
$$

where examined the elements obtained using the Dupont method as factors affecting the return on equity ( $\mathrm{X} \_\mathrm{t}$ and $\mathrm{X} \_0$ ): tax burden ratio, percentage burden ratio, return on sales (ROS), asset turnover and financial leverage.

Thus, 5 equations were obtained that evaluate the effect of each factor on ROE (5-9):

$$
\begin{aligned}
& \triangle R O E_{n T}=\frac{R O E t-R O E 0}{\ln (\text { ROEt })-\ln (\text { ROEO })} * \ln \left(\frac{T t}{T 0}\right) ; \\
& \triangle R O E_{n \%}=\frac{R O E t-R O E 0}{\ln (\text { ROEt })-\ln (\text { ROE } 0)} * \ln \left(\frac{\% t}{\% 0}\right) ; \\
& \triangle R O E_{n R O S}=\frac{R O E t-R O E 0}{\ln (\text { ROEt })-\ln (\text { ROE } 0)} * \ln \left(\frac{\text { ROSt }}{R O S 0}\right) ; \\
& \triangle R O E_{n A T}=\frac{R O E t-R O E 0}{\ln (\text { ROEt })-\ln (\text { ROEO })} * \ln \left(\frac{A T t}{\mathrm{AT} 0}\right) ; \\
& \triangle R O E_{n F L}=\frac{R O E t-R O E 0}{\ln (\text { ROEt })-\ln (\text { ROE } 0)} * \ln \left(\frac{\mathrm{FL} t}{\mathrm{FL} 0}\right),
\end{aligned}
$$

where $\mathrm{T}$ is the tax burden ratio,\% is the percentage tax burden ratio, AT is the asset turnover, $\mathrm{FL}$ is the financial leverage.

The main factor in choosing this model for factor analysis was the fact that after applying LMDI there are no indecomposable residues. This confirms the accuracy of the results. However, this method has an important disadvantage: since the calculation of the influence of the factor on the indicator uses logarithms, then in the presence of zeros or negative economic elements, the formula will not yield results. Thus, part of the years under consideration "drop out" of the analysis, since companies have, for example, negative net income. Thus, the analysis does not include some years of companies that had negative economic elements.

\section{Results}

\subsection{Evaluation of return on equity}

The analysis of the profitability of equity for oil and gas companies showed that almost all companies except Slavneft in 2014, Surgutneftegaz in 2016 and Russneft in 2013-2014 effectively use equity. Shareholders receive income from investments, which allows them to attract new deposits in the future.

For a more complete analysis, the authors performed a comparative analysis of the ROE value for each company with an industry average value. Industry ROE in 2018 was $18.2 \%$, and in 2014 it was $18.1 \%$. That is, the return on equity in these two years was the same, but the distribution of companies that have the value of this indicator is significantly different. So, in 2014, only 2 companies exceeded the industry average ROE - Surgutneftegas and Bashneft. The remaining companies are less profitable than the entire industry. In 2018, the 
situation changed dramatically: only 2 companies have a value below the industry average Rosneft and Lukoil. Such results indicate that the state of the industry is gradually improving and most companies manage to successfully adapt to economic, political and geopolitical challenges (Table 1).

Table 1. The efficiency of the oil and gas industry based on ROE (\%).

\begin{tabular}{|c|c|c|c|c|c|c|}
\hline Company & $\mathbf{2 0 1 3}$ & $\mathbf{2 0 1 4}$ & $\mathbf{2 0 1 5}$ & $\mathbf{2 0 1 6}$ & $\mathbf{2 0 1 7}$ & $\mathbf{2 0 1 8}$ \\
\hline Rosneft & 17,7 & 12,2 & 12,3 & 5,8 & 8,2 & 16,0 \\
\hline Lukoil & - & 13,0 & 9,1 & 6,0 & 13,0 & 15,3 \\
\hline Surgutneftegaz & 13,5 & 30,4 & 21,3 & $-1,8$ & 5,4 & 19,2 \\
\hline Gazpromneft & 19,6 & 11,9 & 10,0 & 15,4 & 17,4 & 21,8 \\
\hline Tatneft & 15,5 & 16,8 & 16,1 & 15,0 & 17,2 & 27,2 \\
\hline Bashneft & 19,5 & 21,9 & 25,5 & 19,8 & 37,5 & 21,5 \\
\hline Slavneft & 18,8 & $-14,8$ & 24,7 & 30,2 & 19,9 & 24,5 \\
\hline Russneft & $-54,1$ & $-25,2$ & 123,9 & 29,8 & 14,1 & 24,9 \\
\hline Industry & 17,4 & 18,1 & 14,3 & 5,9 & 11,1 & 18,2 \\
\hline
\end{tabular}

\subsection{Assessment of the influence of factors on the change in return on equity}

The factor analysis of oil and gas companies was performed for two years (2017 and 2018). So, in 2017 , the percentage of the burden has the greatest positive impact on the change in the profitability of equity (Table 2).

Table 2. ROE factor analysis using the Dupont model, 2017, \%.

\begin{tabular}{|c|c|c|c|c|c|c|}
\hline Company & $\Delta \mathbf{R O E}_{\text {ros }}$ & $\Delta \mathbf{R O E}_{\%}$ & $\Delta \mathbf{R O E}_{\mathbf{T}}$ & $\Delta \mathbf{R O E}_{\mathbf{A T}}$ & $\Delta \mathbf{R O E}_{\mathbf{F L}}$ & $\Delta \mathbf{R O E}$ \\
\hline Rosneft & $-1,8$ & 0,2 & 3,3 & 0,6 & 0,0 & 2,4 \\
\hline Lukoil & 0,7 & $-0,5$ & 5,0 & 0,8 & 1,1 & 7,1 \\
\hline Gazpromneft & 0,3 & 0,5 & $-0,4$ & 1,4 & 0,1 & 1,9 \\
\hline Tatneft & $-2,1$ & $-0,6$ & 2,6 & 2,4 & 0,0 & 2,3 \\
\hline Bashneft & 19,7 & $-1,2$ & 5,9 & $-2,8$ & $-4,0$ & 17,6 \\
\hline Slavneft & $-6,8$ & 0,9 & $-4,3$ & $-1,4$ & 1,3 & $-10,2$ \\
\hline Russneft & $-7,6$ & 1,6 & $-11,1$ & 3,3 & $-1,9$ & $-15,7$ \\
\hline Industry & $-0,2$ & 6,6 & $-2,1$ & 0,6 & 0,4 & 5,2 \\
\hline
\end{tabular}

According to the analysis of return on equity, oil and gas companies in 2017 can be divided into several groups depending on the factor that largely affects the ROE:

- Companies with the maximum influence of the tax burden ratio (Rosneft, Lukoil, Tatneft, Russneft);

- Companies with the greatest impact of asset turnover (Gazpromneft);

- Companies with the greatest influence of profitability of sales (Bashneft, Slavneft).

It has been established that the influence of the same factor can be multidirectional, depending on the company and the year of analysis. This is due to the ratio of economic elements used in calculating factors. For example, for Rosneft, the influence of ROS on ROE is negative, while for Lukoil it is positive. This is due to the fact that the value of sales profitability for the first company decreased from 2016 to 2017, while for the second it increased.

The factor analysis of oil and gas companies in 2018 showed that the distribution of the influence of factors on ROE has changed (Table 3). Thus, in the industry, the determining factor is the tax burden ratio, which in 2017 had a slight negative impact. 
Table 3. ROE factor analysis using the Dupont model, 2018, \%.

\begin{tabular}{|c|c|c|c|c|c|c|}
\hline Company & $\Delta \mathbf{R O E}_{\text {ros }}$ & $\Delta \mathbf{R O E}_{\%}$ & $\Delta \mathbf{R O E}_{\mathbf{T}}$ & $\Delta \mathbf{R O E}_{\mathbf{A T}}$ & $\Delta \mathbf{R O E}_{\mathbf{F L}}$ & $\Delta \mathbf{R O E}$ \\
\hline Rosneft & 6,4 & 0,7 & $-1,7$ & 2,9 & $-0,5$ & 7,8 \\
\hline Lukoil & 1,6 & 0,1 & $-0,5$ & 3,0 & $-2,0$ & 2,2 \\
\hline Surgutneftegaz & 1,6 & $-4,3$ & 15,6 & 1,0 & $-0,1$ & 13,8 \\
\hline Gazpromneft & 3,9 & 0,3 & $-1,4$ & 1,3 & 0,3 & 4,4 \\
\hline Tatneft & 5,7 & 0,8 & $-1,1$ & 4,6 & 0,1 & 10,0 \\
\hline Bashneft & $-17,2$ & 0,2 & $-1,1$ & 6,3 & $-4,1$ & $-15,9$ \\
\hline Slavneft & 3,9 & $-0,5$ & $-1,1$ & 2,4 & $-0,2$ & 4,5 \\
\hline Russneft & 9,5 & 2,2 & $-4,4$ & 3,8 & $-0,4$ & 10,8 \\
\hline Industry & 3,1 & $-20,4$ & 22,6 & 2,8 & $-0,9$ & 7,1 \\
\hline
\end{tabular}

The grouping of companies in 2018 will be as follows:

- Companies with the greatest influence of profitability of sales (Rosneft, Gazpromneft, Tatneft, Bashneft, Slavneft, Russneft);

- Companies with the greatest impact of asset turnover (Lukoil);

- Companies with the greatest impact of the tax burden (Surgutneftegaz).

\section{Discussion}

In most companies, the return on sales has the greatest impact on the ROE, which is logical, since in 2018 the companies significantly increased revenue due to favorable oil prices and positive exchange rate differences. At the same time, it can be noted that the profitability of sales has a positive impact on all companies except Bashneft, which showed a decrease in net profit. You can also pay attention to the fact that the asset turnover in 2018 had only a positive impact on the return on equity.

Thus, we can conclude that the effect of the certain factor on the profitability of sales largely depends on the development strategy of the company for the coming year, and on the economic and political situation. Based on forecasts of oil prices, raw materials, knowing the planned volume of production and sales, the development strategy of their company, management can calculate which factor will have the greatest positive or negative impact on the rate of return on equity. This means that the company will understand what they need to pay attention to achieve the target ROE.

As part of the study, an analysis was made of the performance of Russian oil and gas companies based on ROE (return on equity). The calculation results showed that the most effective for this indicator in the period 2013-2018 was the activity of Bashneft. Prior to the calculations and analysis, it was assumed that such companies would be Rosneft, which is a leader in the oil and gas industry. However, this hypothesis has not been confirmed in practice.

The factor analysis of return on equity confirmed the expectation that the company's revenue has the greatest impact on the change in the indicator due to its volume and growth rate. It was also identified the main factor that affects the value of return on equity - return on sales.

The factor analysis of ROE allowed us to divide the companies into groups: companies with the greatest influence of profitability of sales (Rosneft, Gazpromneft, Tatneft, Bashneft, Slavneft, Russneft); companies with the greatest impact of asset turnover (Lukoil); companies with the greatest impact of the tax burden (Surgutneftegas). 


\section{Conclusion}

The oil and gas industry of Russia is one of the generators of the country's economic development, therefore, analysis of its financial and economic condition is a necessary part of assessing the state of the Russian economy as a whole.

If we know how and how much each factor considered by the authors as part of factor analysis affects the profitability of own funds, company management can achieve its goals in achieving certain ROE values.

The oil and gas industry makes a significant contribution to national security and socioeconomic development of the country. Taking into account the potential of and gas industry to expand hydrocarbon production, it will continue to remain the main sector of the country's economy, the engine of import substitution, financial stability of the budget and the guarantor of the country's international obligations.

The authors are grateful for financial support to Russian Foundation for Basic Research № 18-01001032 and to Grant of the President of the Russian Federation № HШ-2571.2020.6.

\section{References}

1. I. Filimonova, L. Eder, M. Mishenin, T. Mamakhatov, IOP Conference Series: Earth and Environmental Science 84, 0120112017 (2017)

2. A. Kontorovich, L. Burshtein, V. Livshits, S. Ryzhkova, Herald of the Russian Academy of Sciences 89, 558-566 (2019)

3. L. Eder, I. Filimonova, V. Nemov, I. Provornaya, International Journal of Energy Economics and Policy 8, 74-80 (2018)

4. L. Eder, I. Filimonova, V. Nemov, I. Provornaya, Economy of Region 13, 859-870 (2017)

5. X. Zhang, B. Su, J. Yang, J. Cong, Journal of Cleaner Production 238117897 (2019)

6. C. Xia, Z. Wang, Journal of Cleaner Production, 254120107 (2020)

7. T.S. Ong, T.B. Heng, N. Ahmad, H. Muhamad, Institutions and Economies 7, 56-84 (2015)

8. B. Misund, M. Sikveland, Journal of Energy Markets 11, 1-19 (2018)

9. A.H. Sabet, M. Agha, R. Heaney, Energy Economics 70, 190-204 (2018)

10. A.K. Sar, Academy of Accounting and Financial Studies Journal 21, 7-19 (2017)

11. J. Chen, M. Gao, D. Li, M. Song, Q. Xie, J. Zhou, Mathematical Problems in Engineering 2020, 9207896 (2020) 